\section{Factors Affecting Household Expenditure using OLS Method: A Case Study of Ward Number 6 of Sidhalek Rural Municipality, Dhading, Nepal}

Krishna Prasad Acharya

Submitted: I7 August 2021; Accepted: 18 October 2021

Published online: 5 December 2021

DOI: https://doi.org/ $0.3126 /$ njs.v5il.4I 228

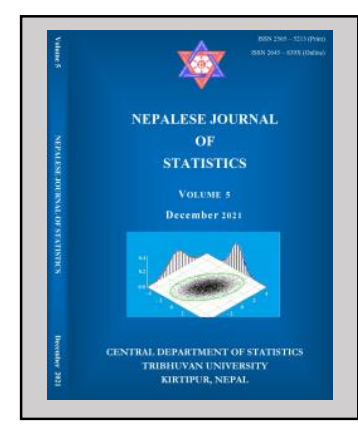

\begin{abstract}
Background: The role of annual household expenditure is very important to run a family smoothly. It incorporates the total expenditure of a family who is residing in a house for their livelihood. There are different factors associated with annual household expenditure, and the assessment of them and identification of such factors play a vital role in the concerned area.

Objective: To identify the most significant factors associated with annual household expenditure using an appropriate statistical model.

Materials and Methods: The study based on cross-sectional study design with 168 households from ward number 6 of Sidhalek rural municipality of Dhading district were considered for the analysis. The multiple linear regression model followed by appropriate bivariate analysis was used to identify the significant factors associated with the outcome variable.

Results: Number of literate persons of working age ( $\beta=0.018,95 \% \mathrm{Cl}: 0.004-0.032)$, remittancereceiving status $(\beta=0.093,95 \% \mathrm{Cl}: 0.026-0.160)$, and gender of household head $(\beta=0.089,95 \%$ $\mathrm{Cl}: 0.023-0.155)$ was significantly associated with the annual household expenditure. The goodness of fit and diagnostics of the fitted model were also performed.

Conclusion: The annual household expenditure is significantly higher among those households having more literate persons of working age, headed by a male and receiving remittance. Considerable improvements need to be made towards the improvements on human capital and remittance-receiving status particularly in the rural area of Nepal.
\end{abstract}

Keywords: Expenditure, linear regression, literate, remittance, Sidhalek.

Address correspondence to the author: Shanker Dev Campus, Tribhuvan University, Kathmandu, Nepal. Email: acharyakrishna20@gmail.com 


\section{INTRODUCTION}

Household expenditure is referred to as the total expenses made by a family residing in a house for its livelihood in terms of food, clothes, shelter, education, health and sanitation, services and entertainment. It is complex in nature and can't be measured precisely. Due to a higher illiteracy rates in developing and the least developed countries, most of the household heads are unable to estimate their annual/ monthly household expenditure. Therefore, their annual/ monthly household expenditure estimates were approximated. On the other hand, literate people can precisely calculate their household expenditures as they generally keep track of their expenses even in the developing or the least developed countries. Household expenditure is considered as an adequate measure of household welfare in developingcountries as it is better able to capture household consumption capabilities. In most developing countries, the information regarding household income is generally not transparent. Therefore, in order to measure the household welfare, the basis of annual household expenditure is preferred instead of annual household income (UNSD, 2005). Household is considered as poor when household expenditure is insufficient to meet the food and other basic needs of all household members (Bogale and Korf, 2009). Age of household head, total household income, and household size, tenure of residence, household head's marital status, and occupation are the factors affecting the expenditure (Enbeyle et al., 2020).

Annual household expenditure is different in urban (NRs. 277,134) and rural (NRs. 142,64I) areas of Nepal (CBS, 20II)). The exact household expenditure can be ascertained in the densely populated area where there is no agricultural land. But in the rural areas where the plenty of agricultural lands is available and the population density is low, actual household expenditure cannot be measured. People residing in the least densely populated area spend their money on education, health, services, entertainment, and in buying commodities needed for agriculture (seeds, fertilizers, animals, etc.). These people don't take account of the value/cost of the goods they produce on theirown. Therefore, analyzing household expenditure in these areas could be inaccurate and misleading. Sidhalek rural municipality is in Dhading district of Bagmati province of Nepal. The total area of this rural municipality is $106.36 \mathrm{sq}$. km. comprising of 6212 households with a total of 31,395 population. The main occupation of the people living in this area is agriculture (Gaunpalika Samnchhipta Janakari, 2075). Ward no. 6 of this rural municipality has the male and female household heads as 548 and 85 , respectively, resulting in 633 houses. The female and male populations residing in this ward are 1543 and $165 \mathrm{I}$, respectively. There are 5 primary schools and one health post in this ward (Gaunpalika Samnchhipta Janakari, 2075). The main objective of this study is to investigate factors affecting an annual household expenditure of this ward which is exclusively rural in nature and also adjoining with national highway. Since the actual expenditure of the people in such areas is not obvious, an attempt has been made to identify the significant factors associated with annual household expenditure. 


\section{MATERIALS AND METHODS \\ Data}

Dhading is the district adjacent to the capital city, Kathmandu, and Ward no. 6 of Sidhalek is the only one ward that is adjoining with Prithvi national highway. This study is based on the household level data collected from the households of ward number 6 of Sidhalek rural municipality of Dhading district of Nepal. This ward is comprised of total of 633 households, among them, 168 households were selected from this ward using a simple random sampling method. In order to select the sample households in the study, all the list of 633 households were taken from the ward office and maintained in Microsoft Excel. These all households were coded and then from the total list of these households, 168 households were selected randomly keeping in view the resource constraints. Finally, the selected households were decoded for the sample survey. The questionnaire to collect the information was prepared partially adopting previously published relevant studies (Ajmair and Akhtar, 2012; Sekhampu and Niyimbanira, 2013; Heshmati, Maasoumi, \& Wan, 2019) and finalized discussing, with concerned experts. The data were collected by the researcher visiting the selected households for the survey in February 202I. In this study, the outcome of interest is annual household expenditure (in NRs.). In order to assess the association of each independent variable with an outcome variable, bivariate correlation and independent sample t-test were used. These tools helped us identify the candidate variables for multiple regression model.

\section{The statistical model and its goodness of fit}

The effects of different socio-economic variables on household expenditure per capita have been assessed through the ordinary least square (OLS) regression method. Researchers such as Akerele and Adewuyi (20I I), Chaudhary et al., (2009), Salami and Atiman (2013), Sinnathurai and Brezinova (20I2), Sanusi and Akinniran (20I3). Sakiru (20I3) applied the regression method to identify important socio-economic characteristics, household characteristics, and/or community characteristics associated with household welfare. Other researchers such as Belete, et al., (1999), Ajmair and Akhtar (20I2), Sekhampu and Niyimbanira (20I3), Hone and Marisennayya (20I9), Bakri, et al. 2017), and Zeynaloya and Mammadli (2020) applied the OLS regression method to identify the important socio-economic characteristics, household characteristics, and/or community characteristics associated with household expenditure. Since the response variable of the study was annual household expenditure, the ordinary least square(OLS) regression method was used to investigate the relationship between the response variable and explanatory variables. The annual household expenditure did not seem to be normally distributed and it varied extremely. Therefore, the logarithmic transformation of the outcome variable was used while performing multiple linear regression analyses. The mathematical model of multiple regression is expressed as follows.

$\ln (Y)=\beta_{0}+\beta_{1} X_{1}+\beta_{2} X_{2}+\ldots+\beta_{n} X_{n}+\varepsilon$

where 
$\ln (Y)$ is response variable (Annual household expenditure in log scale)

$\beta_{0}$ is the intercept

$\beta_{i}$ 's are unknown parameters

$X_{i}$ 's are explanatory variables

$\varepsilon$ is the error term

$i=\mathrm{I}, 2, \ldots, \mathrm{n}$.

Model parameters were estimated using the ordinary least square (OLS) method. Statistical software SPSS (version 20) was applied in analyzing and fitting models in this study, and the results were considered statistically significant if $p$ - value $<0.05$ at $5 \%$ level of significance. The model adequacy was assessed by using $R^{2}$. The variables in the multiple regression model were finalized through the use of the stepwise selection method.

\section{Diagnostics of the model}

In order to assess the fitted multiple regression model, mainly two plots were used. Normal P-P plot and scatter plot of regression standardized residual were attempted. The normality of the residuals was assessed using the Kolmogorov-Smirnov (K-S) test and the Shapiro-Wilk test.

\section{RESULTS}

Keeping in view to address the objective of the study, the outcome variable and the predictor variables are explained. Further, the results of the analysis for the identification of factors affecting annual household expenditure have also been explained. The average annual household expenditure (Mean \pm S. D.) is NRS. (155785.7I \pm 51692.79$)$ with average household size, the number of children, and the number of literate persons of working age are (5.99 \pm 1.79$),(1.48 \pm$ I.78), and (3.67 \pm 1.57$)$ respectively as shown in Tablel.

Table I. Summary statistics of quantitative variables.

\begin{tabular}{|c|c|c|c|}
\hline Variables & Mean \pm S. D. & Minimum & Maximum \\
\hline Annual household expenditure(NRS) & $|55785.7| \pm 5 \mid 692.79$ & $60,000.00$ & 300000.00 \\
\hline Households size & $5.99 \pm 1.79$ & 3 & 14 \\
\hline Number of children & $1.48 \pm 1.78$ & 0 & 5 \\
\hline Number of literate persons of working age & $3.67 \pm 1.57$ & 0 & 9 \\
\hline
\end{tabular}

It shows that the annual household expenditure, household size, and number of literate persons of working age were highly variated. Table 2 shows the demographic distribution of households of ward number 6 of Sidhalek rural municipality. The proportion of male (87.5\%), literate household head (70.8\%), agriculture occupation household head (92.9\%), not receiving remittance $(88.1 \%)$ to be higher among the counterparts. 
Table 2. Summary statistics of dummy variables.

\begin{tabular}{ll}
\hline Variables & Number (\%) \\
\hline $\begin{array}{l}\text { Gender of household head: } \\
\text { Female }\end{array}$ & $2 \mathrm{I}(12.5)$ \\
Male & $147(87.5)$ \\
\hline Literacy status of household head:Literate & $119(70.8)$ \\
$\begin{array}{l}\text { Illiterate } \\
\text { Occupation of household head: }\end{array}$ & $49(29.2)$ \\
$\begin{array}{l}\text { Agriculture } \\
\text { Others }\end{array}$ & $156(92.9)$ \\
\hline Remittance-receiving status of household: & $12(7.1)$ \\
Not receiver & $148(88.1)$ \\
Receiver & $20(11.9)$ \\
\hline
\end{tabular}

Out of seven household level independent variables (shown in tablel and table 2), three quantitative variables namely household size, number of children, and number of literate persons of working age, and four dichotomous namely gender of household head, literacy status of household head, occupation of household head, and remittance-receiving status were considered important variables. The association of each quantitative independent variable with the response variable (annual household expenditure in log scale) was assessed by using Pearson's correlation coefficient (Table 3) and the association of each dichotomous variable with the response variable was assessed by using independent t-test (Table 4). Only the significantly associated variables (at $5 \%$ level of significance) with the response variable were included in multiple regression analysis.

Table 3. Correlation matrix of household size, number of children, number of literate persons with annual household expenditure (in Log scale).

\begin{tabular}{lcccc}
\hline & $\begin{array}{c}\text { Annual } \\
\text { household } \\
\text { expenditure in } \\
\text { log scale }\end{array}$ & $\begin{array}{c}\text { No. of literate } \\
\text { persons of working } \\
\text { age }\end{array}$ & $\begin{array}{c}\text { Household } \\
\text { size }\end{array}$ & No. of children \\
\hline $\begin{array}{l}\text { Annual household } \\
\text { expenditure in log scale }\end{array}$ & 1.0 & 0.259 & 0.112 & 0.050 \\
\hline $\begin{array}{l}\text { No. of literate persons } \\
\text { of working age }\end{array}$ & 0.259 & $(0.001)$ & $(0.149)$ & $(0.518)$ \\
\hline Household size & $(0.001)$ & 1.0 & 0.528 & -0.064 \\
& 0.112 & 0.528 & 1.0 & $(0.407)$ \\
\hline No. of children & $(0.149)$ & $(p<.001)$ & 0.514 \\
& 0.050 & -0.064 & 0.514 & $(p<.001)$ \\
\hline
\end{tabular}

Figures in parentheses are $p$-values at $5 \%$ level of significance. 
The results indicated that the number of literate persons of working age were found to be significant factors associated with annual household expenditure (in log scale) under this study (Table 3).

Table 4. Association of categorical independent variables with the annual household expenditure (in Log scale).

\begin{tabular}{|c|c|c|c|}
\hline Independent variables & $\begin{array}{l}\text { Annual household expenditure(in } \\
\text { log scale) Mean } \pm \text { S.D. }\end{array}$ & $\mathrm{t}$ - value & $\mathrm{p}$-value \\
\hline \multicolumn{4}{|c|}{ Gender of household head: } \\
\hline$\overline{\text { Male (I) }}$ & $5.181 \pm 0.134$ & -3.002 & 0.003 \\
\hline Female (0) & $5.078 \pm 0.215$ & & \\
\hline \multicolumn{4}{|l|}{ Literacy status } \\
\hline Literate $(0)$ & $5.183 \pm 0.132$ & 2.083 & 0.039 \\
\hline Illiterate (I) & $5.131 \pm 0.181$ & & \\
\hline \multicolumn{4}{|c|}{ Occupation household head } \\
\hline Agriculture (0) & $5.169 \pm 0.151$ & 0.602 & $\overline{0.548}$ \\
\hline Others (I) & $5.143 \pm 0.132$ & & \\
\hline \multicolumn{4}{|c|}{ Remittance-receiving status } \\
\hline Not receiving $(0)$ & $5.156 \pm 0.147$ & -3.001 & 0.003 \\
\hline Receiving I) & $5.260 \pm 0.141$ & & \\
\hline
\end{tabular}

Figures within parentheses are binary codes.

The average annual household expenditure in males is $5.181 \pm 0.134$ and an average annual household expenditure in females is $5.078 \pm 0.215$. Similarly, the average annual household expenditure in literate and illiterate, agriculture and others, not receiving and receiving are 5.183 \pm 0.132 and $5.131 \pm 0.181,5.169 \pm 0.151$ and $5.143 \pm 0.132,5.156 \pm 0.147$ and $5.260 \pm 0.141$ respectively. The results also indicated that literacy status, remittance-receiving status, and gender of household head were found to be significant factors associated with household expenditure (in log scale) under this study(Table 4). Form the bivariate analysis (Table 3 and Table 4), the four variables have come out as candidate variables for multiple regression analysis.

\section{Results of multiple linear regression model}

The stepwise regression was conducted first to identify potential explanatory variables for the multiple linear regression model from the four explanatory variables which had come significantly from the bivariate analysis. Stepwise regression resulted in 3 variables (the number of literate personsof working age, remittance status of household, and gender of household head) to be used in multiple linear regression. The results of the estimated multiple regression model are presented in Table 5. 
Table 5. Model parameter estimates for the selected predictors.

\begin{tabular}{lccccc}
\hline Variable & $\beta$ & S. E. & t-test & P-value & $95 \% \mathrm{Cl}$ \\
\hline Constant & 5.012 & 0.037 & 136.185 & $<0.001$ & $4.940,5.085$ \\
\hline $\begin{array}{l}\text { No. of literate personsof } \\
\text { working age }\end{array}$ & 0.018 & 0.007 & 2.538 & 0.012 & $0.004,0.032$ \\
\hline $\begin{array}{l}\text { Remittance-receiving } \\
\text { status(receiving vs. notreceiving) }\end{array}$ & 0.093 & 0.034 & 2.749 & 0.007 & $0.026,0.160$ \\
$\begin{array}{l}\text { Gender of household } \\
\text { head(male vs. female) }\end{array}$ & 0.089 & 0.033 & 2.671 & 0.008 & $0.023,0.155$ \\
\begin{tabular}{l}
$\mathrm{R}^{2}=0.14$, F-value $=6.876$, sample size $(\mathrm{n})=168$ \\
\hline
\end{tabular}
\end{tabular}

These results indicate that the number of literate persons of working age, remittance status of household, and gender of the household head had the positive and significant effect on annual household expenditure. All these variables were significant in the regression $(p<0.05)$ at the $5 \%$ level of significance. Fourteen percent of the variation of the outcome variable (log of annual household expenditure) has been explained by independent variables $\left(R^{2}=0.14\right)$. The F-value (6.876) shows the importance of these independent variables in influencing annual household expenditure (Table 5). The number of literate persons of working age has helped to develop human capital and participate in the labor market resulting in improving people's welfare. Besides, additional literate persons of working age had the significant effect on average yearly household expenditure ( $\beta=0.018,95 \%$ C.I.:0.004, 0.032). If other predictors were held constant, the annual household expenditure would increase by $1.8 \%$ by increasing an additional literate person of working age. Similarly, remittance receiving status was another important variable for average yearly household expenditure $(\beta=0.093,95 \%$ C.I.:0.026, 0.160),). If other variables are held constant, that the annual household expenditure would be $9.3 \%$ higher for the remittance-receiving households than from remittance not receiving households. Finally, the gender of the household head was also an important variable for average yearly household expenditure ( $\beta=0.089,95 \%$ C.I.: $0.023,0.155$ ). It concluded that household expenditure would be $8.9 \%$ higher for the male household heads than for female household heads if other variables remained constant.

\section{Results for regression diagnostics}

The regression diagnostics has been attempted using different plots. The normal probability plot of residuals (Figurel) demonstrates that there is no violation of the normality assumption of the residuals generated from the regression model since the majority of the dots are found lying across the straight line. 


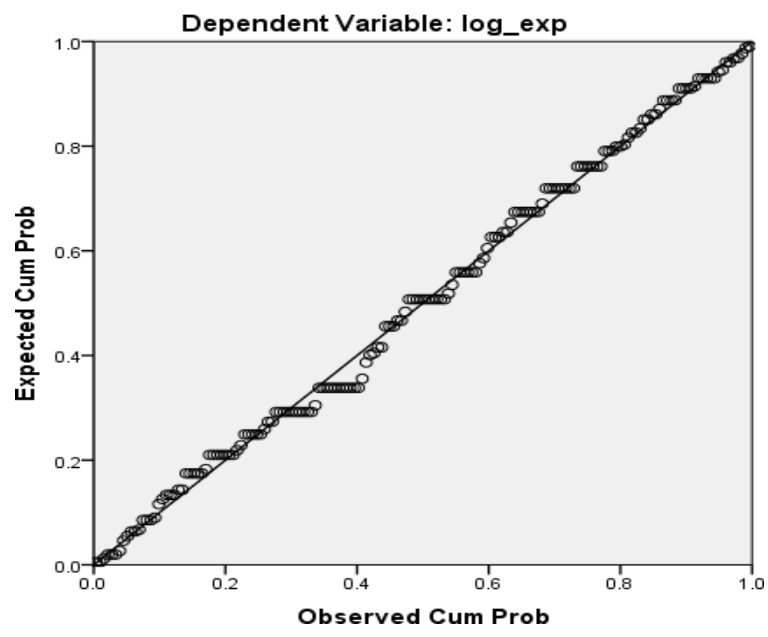

Fig. I. Normal P-P plot of residuals.

Heteroscedasticity was checked by plotting residuals against fitted values (Figure 2). The residualsare reasonably randomly distributed and there is no sign of much heteroscedasticity in the data set. This shows that the standardized residuals are uncorrelated with the fitted value. Therefore, the plot does not seem to be the non-random and does not have any systematic pattern.

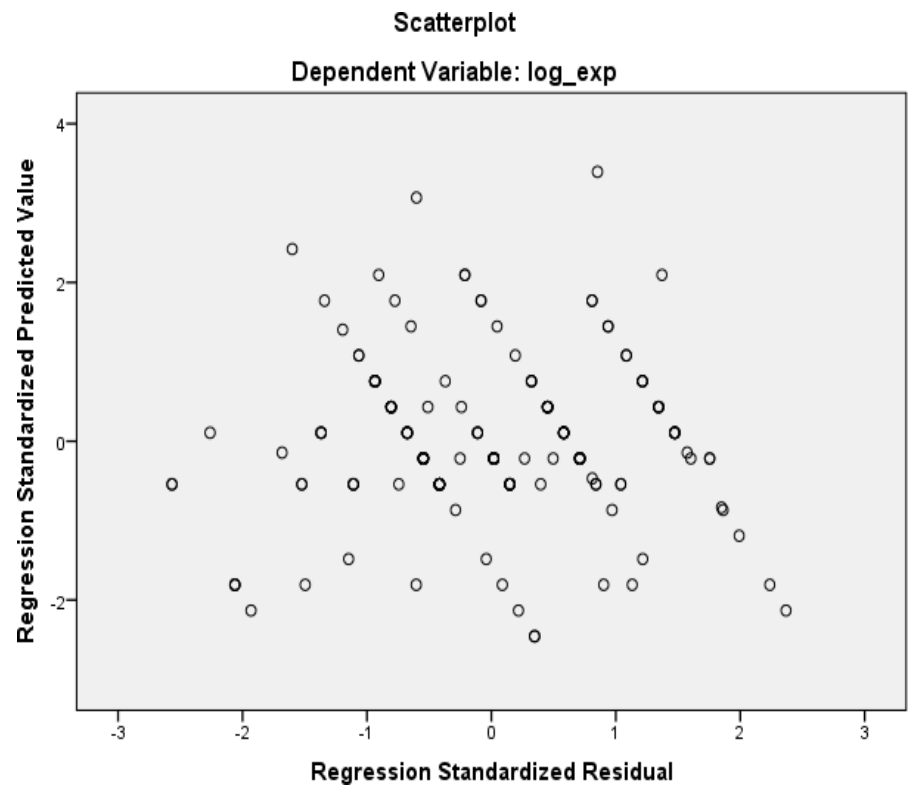

Fig. 2. Scatter plot residuals and regression predicted value.

Similarly, Kolmogorov-Smirnov and Shapiro-Wilk tests were also conducted to check the 
normality of the residuals as shown in Table 6. The values of the Kolmogorov-Smirnov and ShapiroWilk tests were 0.065 and 0.995 , respectively, with the $p$-value $>0.05$ for each. As aresult, these tests are statistically insignificant indicating that the residuals do not violate the normality assumption.

Table 6. Kolmogorov-Smirnov (K-S) and Shapiro-Wilk test.

\begin{tabular}{lcclccc}
\hline Kolmogorov-Smirnov (K-S) & & & \multicolumn{3}{c}{ Shapiro-Wilk } \\
\hline & Statistic & DF & p-value & Statistic & DF $p$-value \\
\hline Unstandardized Residual & 0.065 & 168 & 0.085 & 0.995 & 1680.803 \\
\hline
\end{tabular}

Multicolinearity in the data set was checked by calculating VIF for each quantitative as well as dummy variables (Table 7). The VIF values were very low and not greater than even I.I indicating that there are no issues related to multicolinearity.

Table 7. Collinearity statistics.

\begin{tabular}{ll}
\hline Variables & Collinearity Statistics (VIF) \\
\hline No. of literate persons of working age & 1.066 \\
\hline Remittance-receiving status & 1.030 \\
\hline Gender of household head & 1.039 \\
\hline
\end{tabular}

\section{DISCUSSION}

From the results discussed above (figures I \& 2 and tables 6 \& 7), it is obvious that all assumptions made about least squares regression (errors are normally distributed with constant variance and uncorrelated) were satisfied. Kolmogorov-Smirnov test and Shapiro-Wilk test were statistically insignificant indicating that the residual is following the normal distribution. Similarly, there is no severe problem of multicollinearity assessed through Variance Inflation Factor (VIF) as it varies from I.030 to I.066. Considerable multicolinearity, logical incorporation of independent variables in the model can be considered to be fine even having low $\mathrm{R}^{2}$ value. The positive regression coefficient $(0.018)$ of the number of literate persons of working age implied annual household expenditure increased by increasing the number of literate persons of working age. The similar result was found by Sekhampu and Niyimbanira, (2013). Educated households have higher consumption because they try to maintain a certain standard of living (Ajmair and Akhtar, 2012). Similarly, the regression coefficient of the number of remittance-receiving households (0.093) implied that an increase of the remittance-receiving households would lead to the $9.3 \%$ increase in the annual household expenditure keeping the effects of other variables constant. Thapa and Acharya (2017) found similar results and concluded that the remittance recipient household spent on consumption, health, and education more compared to remittance non-receiving households. Devkota (2014) found that the probability of receiving remittance was higher in richer households than the poorer households. The regression coefficient 0.089 of the gender of the 
household head implies that annual household expenditure would be $8.9 \%$ higher for the maleheaded households than from female-headed households. On the contrary Sekhampu and Niyimbanira, (2013) found that the gender of household head was not important in explaining the variations in household expenditure. The findings of this study may not be generalized other than the study area since this study represents a case study of the rural municipality of Dhadhing district of Nepal. One can plan the extensive study considering such area of study with the sufficiently larger sample size in order to generalize the results covering the wider area.

\section{CONCLUSION}

Our study showed that annual household expenditure is significantly, and positively affected by the number of literate persons of working age, remittance status of household and gender of the household head. Considerable improvements particularly in the rural area, human capital, and remittance play key role in annual household expenditure in Nepal.

\section{CONFLICT OF INTEREST}

The author declares that there is no conflict of interest.

\section{ACKNOWLEDGEMENTS}

Author would like to acknowledge all the respondents of ward no. 6 of Sidhalek rural municipality of Dhading district. Mr. Govinda Prasad Pandit (teacher) and Mr. Krishna Prasad Khatiwada (headmaster) of Sundari secondary school, ward number 6, Sidhalek rural municipality of Dhading are also highly acknowledged for supporting and providing different information during this study.

\section{REFERENCES}

Ajmair, M., \& Akhtar, N. (20I2). Household Consumption in Pakistan (A case study of district Bhimber, AJK). European Journal of Scientific Research, 75(3), 448-457.

Akerele, and Adewuyi, S.A. (20II). Analysis of Poverty Profiles and Socioeconomic Determinants of Welfare among Urban Household of Ekiti State, Nigeria. Current Research Journal of Social Sciences 3(1), I-7.

Arapova, E. (2018). Determinants of Household Final Consumption Expenditures in Asian Countries: A Panel Model, 1991-2015. Applied Econometrics and International Development, /8(I), I2I-I40.

Bakri, S. M., Rambeli, N., Hashim, E., Mahdinezhad, M., \& Jalil, N. A. (2017). Understanding Behavior of consumption expenditure of households. International Business Education Journal, 10 , 43-52. Retrieved from https://www.researchgate.net/publication/322222849

Belete, A., Igodan, C. O., M'marete, C., \& Van Averbeke, W. (1999). Analysis of Rural household consumption expenditure in South Africa: the case of food plot holders in tyefu irrigation scheme in the Eastern Cape Province/analyse van verbruiksbesteding van land like huishoudings in suid-afrika:'n gevallestudie van kleinboere in tyefu besproeiingskema in die ooskaap provinsie. Agrekon, 38(2), 194-203. 
Bogale, A., \& Korf, B. (2009). Analysis of poverty and its covariates among smallholder farmer in the eastern Hararghe highlands of Ethiopia (No. 1005-2016-79164). Retrieved from https://ageconsearch.umn.edu/record/5 |469/files/200\%20Bogale\%20and\%20Korf.pdf

CBS. (20II). Nepal Living Standard Survey (20I0/II). Statistical Report, Volume two, Central Bureau of Statistics, National Planning Commission Secretariat, Government of Nepal.

Chaudhry, I. S., \& Malik, S. (2009). The Impact of Socioeconomic and Demographic Variables on Poverty: A Village Study. Lahore Journal of Economics, I4(I).

Devkota, J. (2014, March). Impact of migrants' remittances on poverty and inequality in Nepal. In Forum of International Development Studies, 44, 36-53.

Enbeyle, W., Meslie, Y., and Pandey, D. (2020). Determinants of Household Consumption Expenditure in Tepi Town, SNNPR, Ethiopia. International Journal of Intelligent Computing and Technology, 4 (I), 40-56.

Gaunpalika Samnchhipta Janakari. (2075). Sidhalek.

Heshmati, A., Maasoumi, E., \& Wan, G. (2019). An analysis of the determinants of household consumption expenditure and poverty in India. Economies, 7(4), 96. doi: http://dx.doi.org//0.3390/economies7040096

Hone, Z., \& Marisennayya, S. (2019). Determinants of Household Consumption Expenditure in Debremarkos Town, Amhara Region, Ethiopia. American Scientific Research Journal for Engineering, Technology, and Sciences (ASRJETS), 62(1), 124-144. Retrieved from http://asrjetsjournal.org/

Itaoka,(20I2).Retrievedfromhttps://ieaghg.org/docs/General_Docs/3rd_SRN/Kenshi_Itaoka_Regr essionInterpretationSECURED.pdf

Sakiru, O. A. (2013). Profiles and Determinants of Poverty among Urban Households in SouthWest Nigeria. American Journal of Economics, 3(6), 322-329.

Salami, L. A., \& Atiman, K. (2013). An Analytical Study of Determinants of Poverty Level among Households in Adamawa North District, Nigeria. Mediterranean Journal of Social Sciences, 4(16), 73-73. doi: https://doi.org/10.590I/mjss.2013.v4n 16p73

Sanusi, W.A., and Akinniran, T.N. (2013). Effect of Households Poverty Level on Child Labour Participation among Households in Nigeria. Developing Country Studies 3(7).

Sekhampu, T. J., \& Niyimbanira, F. (20I3). Analysis of the Factors Influencing Household Expenditure in a South African township. International Business \& Economics Research Journal. I2(3). Retrieved from http://www.cluteinstitute.com/

Sinnathurai, V., \& Brezinova O. (20I2). Poverty Incidence and its Determinants in the EstateSector of Sri Lanka. Journal of Competitiveness. 4(I), 44-55.

doi: https://doi.org// 0.744I/joc.2012.01.04

Thapa, S., \& Acharya, S. (2017). Remittances and Household Expenditure in Nepal: Evidence from cross-section data. Economies, 5(2), 16. doi: https://doi.org/10.3390/economies5020016

UNSD (2005). Hand Book on Poverty Statistics: Concepts, Methods and Policy Use. Special Project on Poverty Statistics. 
Zeynalova, Z., \& Mammadli, M. (2020). Analysis of the economic factors affecting household consumption expenditures in Azerbaijan. Journal of Critical Reviews, 7(7), 24I-248. doi: http://dx.doi.org//0.31838/jcr.07.07.40

Reference to this paper should be made as follows:

Acharya, K. P. (202I). Factors affecting household expenditure using OLS method: A case study of ward number 6 of Sidhalek rural municipality, Dhading, Nepal. Nep. J. Stat, 5, 39-50. 